\title{
Alteration and remelting of nascent oceanic crust during continental rupture: Evidence from zircon geochemistry of rhyolites and xenoliths from the Salton Trough, California
}

\author{
A.K. Schmitt ${ }^{\mathrm{a}, *}$, J.A. Vazquez ${ }^{\mathrm{b}}$ \\ a Department of Earth and Space Sciences, UCLA, Los Angeles, USA \\ ${ }^{\mathrm{b}}$ Department of Geological Sciences, California State University, Northridge, USA
}

Received 28 June 2006; received in revised form 20 September 2006; accepted 20 September 2006

Editor: R.W. Carlson

\begin{abstract}
Rhyolite lavas and xenoliths from the Salton Sea geothermal field (Southern California) provide insights into crustal compositions and processes during continental rupture and incipient formation of oceanic crust. Salton Buttes rhyolite lavas contain xenoliths that include granophyres, fine-grained altered rhyolites ("felsite"), and amphibole-bearing basalts. Zircon is present in lavas and xenoliths, surprisingly even in the basaltic xenoliths, where it occurs in plagioclase-rich regions interpreted as pockets of crystallized partial melt. Zircons in the xenoliths are exclusively Late Pleistocene-Holocene in age and lack evidence for inheritance. U-Th isochron ages are: $20.5_{-1.2}^{+1.2} \mathrm{ka}$ (granophyres), 18.3-3.5 $\mathrm{ka}$ (felsite), $30.1_{-12.4}^{+14.1} \mathrm{ka}$ and $9.2_{-6.6}^{+7.0} \mathrm{ka}$ (basalts; all errors $1 \sigma$ ). The dominant zircon population in the rhyolite lavas yielded $\mathrm{U}-\mathrm{Th}$ ages between $\sim 18$ and $10 \mathrm{ka}$, with few pre-Quaternary xenocrysts present. $\delta^{18} \mathrm{O}_{\text {zircon }}$ values are lower than typical crustal basement values, thus ruling out rhyolite genesis by melting of continental crust. Moreover, $\delta^{18} \mathrm{O}_{\text {zircon }}$ values are $\sim 0.5-1.0 \%$ lower than compositions achievable by zircon crystallization from residual melt in equilibrium with unaltered mid-ocean ridge basalt, suggesting that basaltic crust and silicic plutons in the subsurface of the Salton Sea geothermal field isotopically exchanged with meteoric waters. This is evidence for deep-reaching hydrothermal circulation and indicates rhyolite genesis by episodic remelting of altered basalts instead of fractional crystallization of unaltered basaltic magma. (C) 2006 Elsevier B.V. All rights reserved.
\end{abstract}

Keywords: Salton Sea geothermal field; U-238/Th-230; O-18/O-16; zircon; Rift zones

\section{Introduction}

Understanding the thermo-mechanical dynamics of lithospheric deformation during rifting is essential for assessing the resource and hazard potentials associated with continental rupture. The Gulf of California-Salton

\footnotetext{
* Corresponding author. Fax: +1 3108252779.

E-mail address: axel@argon.ess.ucla.edu (A.K. Schmitt).
}

Trough is an outstanding example of ongoing rapid horizontal and vertical deformation, fast sediment accumulation, high heat flow, magmatism and sea-floor spreading that accompanies fragmentation of the North American continental margin [1,2]. Onshore, the region hosts extensive geothermal systems (e.g., Salton Sea, Cerro Prieto), and there is potential for off-shore hydrocarbon and mineral deposits [3]. The main kinematic stages associated with continental rifting and embryonic formation of oceanic crust in the Gulf of California- 
Salton Trough are well understood [4-6]: (1) cessation of Pacific plate subduction at $\sim 12 \mathrm{Ma}$; (2) eastward stepping of the Pacific-North American plate boundary by $\sim 250 \mathrm{~km}$; (3) reorganization of the new plate boundary from a transtensional deformation zone into en-echelon pull-apart basins separated by transform fault systems; and (4) maturation of these pull-apart basins into spreading centers.

The Salton Trough region is the subaerial extension of the Gulf of California rift system, but despite intense geophysical coverage by gravity, seismic and heat-flow surveys, ambiguity exists as to the extent of thinned basement versus young mafic crust and metamorphosed rift-basin sediment [7-10]. Synrift magmatic rocks from the surface and subsurface of the Salton Trough are therefore essential in identifying crustal compositions. Previous studies of igneous rocks in the Salton Sea area recognize a bimodal assemblage of rhyolite lavas and basalt xenoliths, with the basalts resembling mid-ocean ridge basalts (MORB) from the Alarcon and East Pacific Rise spreading centers $[11,12]$. In addition, the rhyolites contain granitic xenoliths. The origins of these rhyolites and the granitic xenoliths are unclear. Different origins have been proposed, including extreme fractionation of basalt, partial melting of hydrous peridotite, partial melting of granitic basement, and assimilation of metasedimentary crust by differentiated basalt $[11,12]$, each having different implications for the thermal and compositional state of the crust.

In contrast to previous geochemical studies that mostly utilized whole-rock analysis, we explore the U$\mathrm{Th}-\mathrm{O}$ isotope and trace element compositions of individual zircon crystals from Salton Buttes lavas and xenoliths in order to delimit the timing and origins of magmatism. Zircon is particularly well-suited due to its stability and the slow diffusion of $\mathrm{Th}, \mathrm{U}$, and $\mathrm{O}$ relative to most other minerals (e.g., [13]) so that it preserves a record of its origins even in the high temperature and fluid flow environment of an active magmatic-geothermal system. We performed $\sim 50$ high spatial resolution ion microprobe analyses of zircon from surface lavas and xenoliths that indicate Late Pleistocene to Early Holocene magmatism between $\sim 30$ and $10 \mathrm{ka}$. We also find magmatic zircon $\delta^{18} \mathrm{O}$ compositions that rule out an origin via anatexis of typical continental crustal sources or differentiation of unaltered mantle melts. Instead, our results reveal two previously unrecognized processes for the origin and composition of Salton Trough silicic magmas: (1) deep-reaching circulation of meteoric waters causing compositional alteration of juvenile mafic crust, and (2) episodic remelting of newly accreted oceanic crust to generate rhyolites.

\section{Geologic background}

\subsection{Salton Trough and Salton Sea geothermal field}

The Salton Trough is a $150-300 \mathrm{~km}$ wide NW-SE trending structural depression that is oriented parallel to the nearby San Andreas fault system. It also forms the transition from the continental rupture zone separating Baja California from mainland Mexico to the San Andreas transform plate boundary. Rapid sedimentation of the Colorado River delta has isolated the Salton Trough from the marine environment of the Gulf since about $\sim 5 \mathrm{Ma}[14]$.

Presently at surface elevations of roughly $-40 \mathrm{~m}$ beneath sea level, this depression is filled up with a 5 $6 \mathrm{~km}$ thick sedimentary sequence that is cut by a series of en-echelon right lateral transform faults, including the active Imperial and Brawley fault zones [15]. The deeper crust comprises a $\sim 7 \mathrm{~km}$ thick transitional layer of intermediate density, and deep high-density basement $[7,8]$. Seismic velocities and reflection patterns for the high density basement suggest crust of oceanic ridge type whose formation is thought to have initiated $\sim 5 \mathrm{Ma}$ ago, in analogy to sea floor spreading ages from the mouth of the Gulf of California [6]. Between dense gabbroic crust $(>15 \mathrm{~km})$ and shallow low-density sediments lies an intermediate-density transitional layer that has been interpreted as greenschist-metamorphic metasediments, thinned remnants of plutonic continental basement, or mafic sill complexes intruded into sedimentary strata $[7,8]$. Seismic profiles indicate large amplitude variations in crustal thickness with a $\sim 21-$ $22 \mathrm{~km}$ Moho depth minimum beneath the trough axis in the Imperial Valley and progressive crustal thickening to $>24 \mathrm{~km}$ towards its flanks [7,8]. Teleseismic imaging has highlighted a prominent low velocity anomaly within the upper mantle beneath the Salton Trough at $\sim 100-150 \mathrm{~km}$ depth interpreted as asthenospheric upwelling with $\sim 1-4 \%$ partial melting [16].

Average heat flow in the Salton Trough $(\sim 140 \mathrm{~mW} /$ $\left.\mathrm{m}^{2}\right)$ is more than twice as high as in the adjacent thickcrust Peninsular Ranges and San Bernardino Mountains and locally peaks at values $>500 \mathrm{~mW} / \mathrm{m}^{2}[10]$. These areas of high heat-flow host several developed geothermal fields: Salton Sea (SSGF), Brawley-Mesquite, East Mesa, Heber, in California and Cerro Prieto in Baja California. Salton Trough geothermal fields range among the Earth's hottest and most productive: measured borehole temperatures at $\sim 3 \mathrm{~km}$ depth in the SSGF boreholes reach $\sim 400{ }^{\circ} \mathrm{C}$ and estimated thermal energy outputs for the SSGF range in the order of $10^{3}-10^{4} \mathrm{MW}[17,18]$. Fluid-flow models constrained 
by vertical temperature profiles and extensive diffusive Ar-loss in detrital K-feldspar from reservoir sandstones yield converging estimates for heating durations in the SSGF of less than a few 10 ka $[18,19]$. U-series disequilibrium in brines suggests similar ages (10$40 \mathrm{ka})$ for the geothermal system [20]. Others, however, argued that cooling of a $\sim 150-200$ ka old plutonic body would also satisfy borehole temperature profiles [17], and evidence for higher palaeotemperatures from fluid inclusions appears to be in conflict with K-feldspar thermochronology [21]. While there is general consensus that igneous intrusive activity ultimately sustains high heat flow and hydrothermal circulation in the Salton Trough, we argue that published age data - as summarized below - are insufficient to precisely determine the onset and duration of magmatism and associated geothermal activity.

\subsection{Magmatism in the Salton Trough}

\subsubsection{Surface volcanism}

A $\sim 7 \mathrm{~km}$ long chain of five rhyolite domes, known as the Salton Buttes, crops out at the SE shore of the Salton Sea (Fig. 1). These domes stand to $\sim 30-40 \mathrm{~m}$ above the valley floor and may be connected in the subsurface by a common feeder dike $[11,22]$. Collectively, the Salton Buttes comprise $\sim 0.5 \mathrm{~km}^{3}$ of lava with an unknown but minor proportion of pyroclastic deposits that are locally preserved as pumice raft along the paleoshorelines of Pleistocene Lake Cahuilla, the predecessor of the early 20th century Salton Sea caused by confluence of human error and Colorado river flood. The only other surface volcano within the Salton Trough is Cerro Prieto, located $\sim 30 \mathrm{~km}$ SE of Mexicali. Cerro Prieto is $\sim 200 \mathrm{~m}$ high and consists of two overlapping dacite domes with a total volume of $\sim 0.6 \mathrm{~km}^{3}$ $[23,24]$.

The Salton Buttes lavas are rhyolites with $\mathrm{SiO}_{2}$ contents between $\sim 72$ and 75 wt.\% [11]. Their $\mathrm{Sr}$ and $\mathrm{Nd}$ isotopic compositions $\left({ }^{87} \mathrm{Sr} /{ }^{86} \mathrm{Sr}=0.70492 ; \varepsilon \mathrm{Nd}=\right.$ +6.3 ; [12]) are distinct from sedimentary rocks within the Salton Trough as well as plutonic rocks from the adjacent Peninsular Ranges. This also holds for the rhyolite whole-rock oxygen isotopic composition $\left(\delta^{18} \mathrm{O}=+6.1 \%\right.$; [25]) when compared to quartz values from sandstones in the Salton Trough or Peninsular granite whole-rocks (both $\sim 10-12 \%$; $[25,26]$ ). Cerro Prieto lavas are less siliceous than Salton Buttes rhyolites, $\left(\mathrm{SiO}_{2}=65\right.$ wt. \%), and have similarly low ${ }^{87} \mathrm{Sr} /{ }^{86} \mathrm{Sr}$ (0.7029-0.7056; [12,23]).

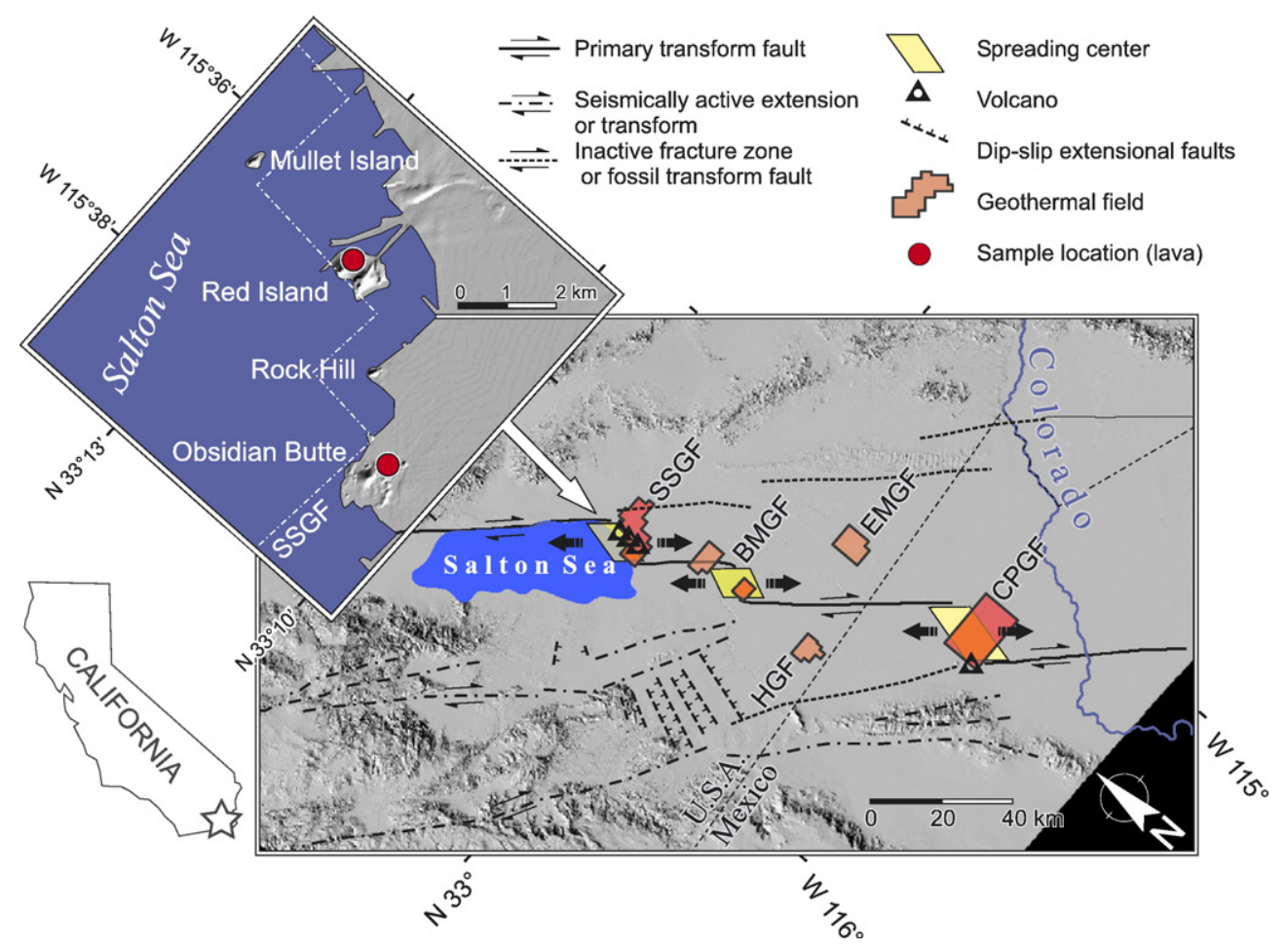

Fig. 1. Overview map of the Salton Trough-Cerro Prieto area in shaded relief showing the location of major active and inactive faults and proposed spreading centers (after [6]). Major geothermal fields in the area are: Salton Sea (SSGF), Brawley-Mesquite (BMGF), East Mesa (EMGF), Heber (HGF), and Cerro Prieto (CPGF). Inset is a close-up of the study area showing the Salton Buttes rhyolite domes and lava sampling locations. 


\subsubsection{Subsurface igneous rocks and xenoliths}

Igneous rocks are penetrated in the subsurface by geothermal wells in the SSGF and other geothermal fields $[11,24,27,28]$. These are typically thin (few to 10 's of $\mathrm{m}$ ) intrusions of basalt, diabase, and/or microgabbro that exhibit variable degrees of hydrothermal alteration $[11,27,28]$. In addition, intermediate (andesitic and dacitic) intrusions are present, and $\sim 100$ 's of $\mathrm{m}$ thick bodies of hydrothermally altered extrusive and intrusive rhyolite have been recently discovered at depths between $\sim 1.6$ and $2.7 \mathrm{~km}$ in the central portion of the SSGF [28].

Several types of igneous xenoliths have been described for Salton Buttes lavas [11,12]: (1) basaltic, (2) granitic, (3) sedimentary, and (4) metamorphic. A 3-cmsized rounded inclusion in obsidian at Red Island (SB0401-i1) is a previously unknown type of xenolith at the Salton Buttes. It has a saccharoidal texture with few feldspar and quartz phenocrysts. Spherulite remnants occur in the fine-grained groundmass. Abundant epidote indicates pervasive alteration. Overall, these textures suggest that this type of xenolith is a devitrified and recrystallized fragment of a buried extrusive or shallow intrusive rhyolite which, for simplicity, will be referred to as "felsite."

Basaltic xenoliths (up to $\sim 5 \mathrm{~cm}$ in diameter) of likely intrusive origin contain plagioclase laths up to $1 \mathrm{~mm}$ in length in a fine-grained groundmass of plagioclase and hornblende along with a minor amount of corroded clinopyroxene and oxides. Plagioclase-rich domains and hornblende clusters are $\sim 1-2 \mathrm{~mm}$ in diameter and give the rocks a speckled appearance. Basaltic xenoliths have low-K tholeiitic compositions with trace element and $\mathrm{Sr}-\mathrm{Nd}$ isotopic characteristics $\left({ }^{87} \mathrm{Sr} /{ }^{86} \mathrm{Sr}=0.70298\right.$; $\varepsilon \mathrm{Nd}=+8.5$; [12]) akin to recent basalts erupted along the East Pacific Rise and the Guaymas and Alarcon rift basins within the Alarcon Basin in the Gulf of California [29-31].

Granitic xenoliths (2-3 cm in diameter) are leucocratic with minor actinolitic hornblende and titanite. They commonly show granophyric textures indicating quench crystallization during rapid cooling due to shallow emplacement and/or efficient fluid convection (e.g., [32]). High ${ }^{87} \mathrm{Sr} /{ }^{86} \mathrm{Sr}$ ratios reported for granitic xenoliths suggested that they may represent fragments or partial melts of basement [11]. This interpretation, however, was later challenged based on low ${ }^{87} \mathrm{Sr} /{ }^{86} \mathrm{Sr}$ $(0.70598)$ and high $\varepsilon N d(+4.5)$ values for another granophyre granite xenolith [12]. Xenoliths of metasedimentary origin, by contrast, show characteristically high ${ }^{87} \mathrm{Sr} /{ }^{86} \mathrm{Sr}$ and low $\varepsilon N d$ values, $(0.71289$ and -11.1 , respectively; [12]).

\subsubsection{Previous age determinations}

Earlier attempts to date the eruption of Salton Buttes rhyolites by $\mathrm{K}-\mathrm{Ar}$ methods produced ages between $33 \pm$ $18 \mathrm{ka}(1 \sigma)$ and $<10 \mathrm{ka}$ [33] Obsidian hydration dating yielded ages between 2.5 and $8.4 \mathrm{ka}$ [33]. Due to erosion of the Salton Buttes lavas by Lake Cahuilla wave action and the active seismicity in the area, we surmise that the oldest obsidian hydration results might be closer to the eruption age. Cerro Prieto is tentatively dated to a Late Pleistocene age, based on two $\mathrm{K}$-Ar dates averaging $108 \pm 46 \mathrm{ka}[34]$.

Two individual basalt xenoliths within Salton Buttes rhyolites were $\mathrm{K}-\mathrm{Ar}$ dated to $0.96 \pm 0.19 \mathrm{Ma}$ and $3.8 \pm$ $0.4 \mathrm{Ma}$ [12]. The lack of detectable radiogenic ${ }^{206} \mathrm{~Pb}^{*}$ in zircons from a granitic granophyre xenolith suggested an age $<100 \mathrm{ka}$ [12]. Available radiometric ages for subsurface basalts $(\mathrm{K}-\mathrm{Ar}$ ages reported for altered basalts from the Brawley geothermal field between 8.1 and 10.5 Ma; [27]) are suspect because they appear older than the age of the sediments they intrude.

\section{Ion microprobe methods}

\subsection{Zircon geochronology}

We analyzed zircons either in-situ in polished thinsections or, when sufficient sample material was available, in grain mounts produced by hand-picking of heavy mineral concentrates $(<250 \mu \mathrm{m}$ sieve fraction; $>3.3 \mathrm{~g} / \mathrm{cm}^{3}$ ). For in-situ analyses, care was taken to have zircon standards available on the same mount to maintain reproducible instrumental mass fractionation by avoiding different ion extraction geometries due to sample changes. This was achieved by drilling a hole $\sim 3 \mathrm{~mm}$ diameter through the thin-section and mounting a prepolished zircon standard epoxy block within the hole. Preparation of the standard block and grain mounts followed standard epoxy mounting and polishing techniques. Backscatter electron (BSE) and cathodoluminescence (CL) imaging was used as a complementary tool during ion microprobe analysis of zircon (Fig. 2).

U-Th zircon dating was performed using the UCLA Cameca ims 1270 secondary ion mass spectrometer (SIMS, ion microprobe) modifying a technique by [35]. Measured ${ }^{238} \mathrm{UO}^{+} / 232 \mathrm{ThO}^{+}$and radiogenic ${ }^{206} \mathrm{~Pb}^{* /}$ ${ }^{208} \mathrm{~Pb}^{*}$ on concordant reference zircons AS-3 [36] and 91500 [37] were used to calibrate $\mathrm{Th} / \mathrm{U}$ relative sensitivity factors (RSF between 0.90 and 0.94 ). ${ }^{230} \mathrm{ThO}^{+}$ intensity was corrected by subtracting the averaged intensities measured during each analysis on two mass stations at 244.038 and 246.300 amu. Mass 244.029 $\left({ }^{232} \mathrm{ThC}^{+}\right)$is monitored as a proxy for ${ }^{232} \mathrm{Th}_{2} \mathrm{CO}^{2+}$ 

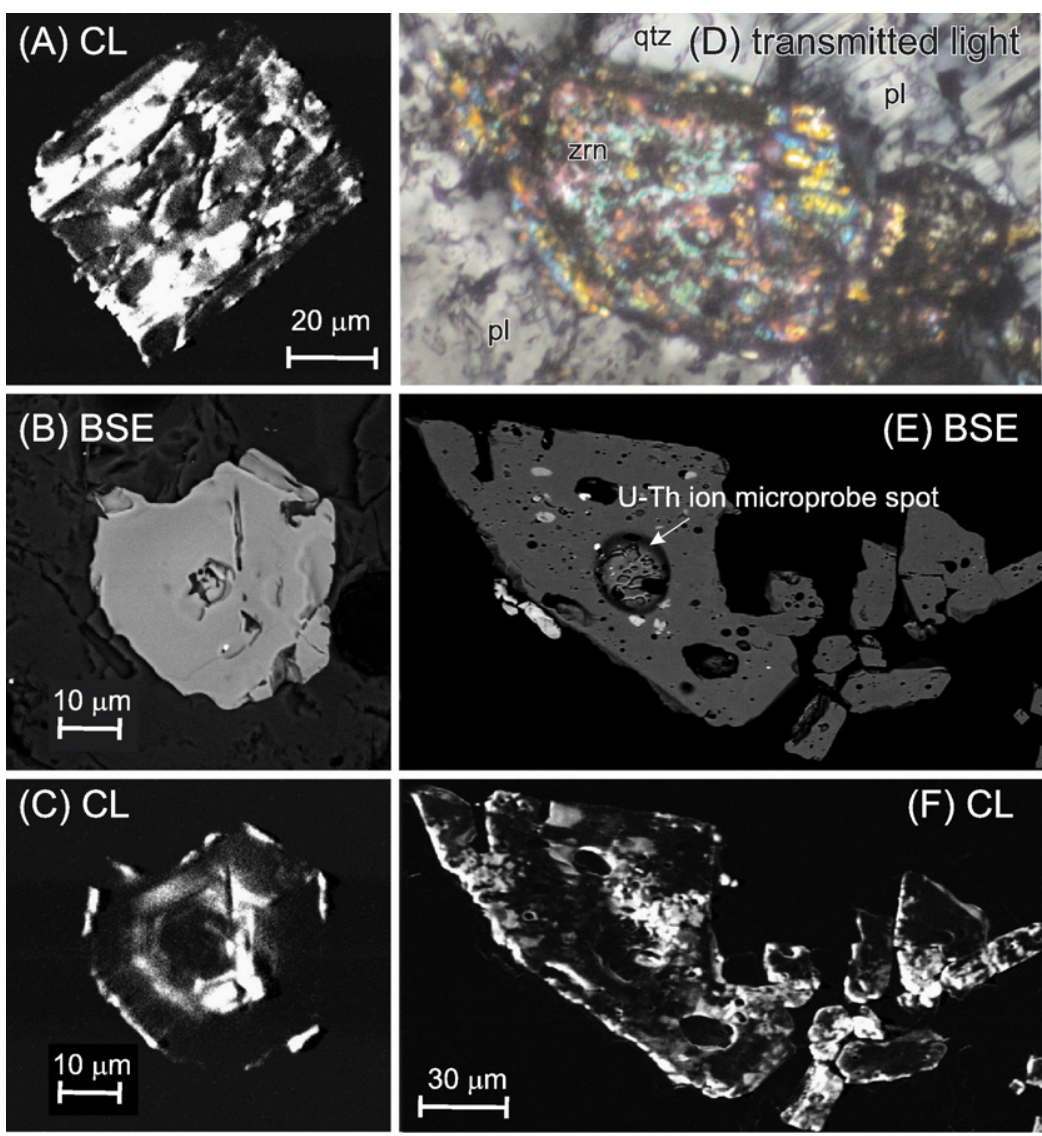

Fig. 2. Zircon images (CL cathodoluminescence; BSE back-scatter electron imaging). (A) Zircon rhyolite lava SB0402 grain 7. Note patchy CL similar to (F). (B) and (C) Zircon from basaltic xenolith. (D)-(F) Zircon from granophyre xenolith SB0402-i1 grain 11 with spongy texture (most obvious in the bottom of the ion microprobe crater) and bright inclusions (Th-rich monazite?) in BSE image.

isobaric interference (resulting from beam overlap of epoxy) on ${ }^{230} \mathrm{ThO}^{+}$. In a few cases, analyses of zircons smaller than the primary beam spot (30-35 $\mu$ m diameter) were affected by unusually high 244.038 intensities, probably due to sampling of epoxy along cracks and grain boundaries; these analyses were discarded. Analyses of grain-mounted zircons did not overlap epoxy due to the larger size of these crystals. Throughout each ion microprobe session, zircon standards 91500 and AS-3, which are in ${ }^{238} \mathrm{U}-{ }^{230} \mathrm{Th}$ secular equilibrium, were intermittently analyzed. The weighted average $\left({ }^{230} \mathrm{Th}\right) /\left({ }^{238} \mathrm{U}\right)$ for five analytical sessions over the period from February 2005 to February 2006 on 91500 and AS-3 zircons is $1.003 \pm 0.007$ ( 1 standard error of the mean; mean square of weighted deviates MSWD $=0.45 ; n=21)$. $\mathrm{U}$ concentration in the zircons is calculated by comparing measured ${ }^{238} \mathrm{UO}^{+} /{ }^{92} \mathrm{Zr}^{94} \mathrm{ZrO}_{4}^{+}$between unknowns and zircon 91500 ([U]=81.2 ppm [37]).

Two xenocrystic zircons in secular equilibrium were re-analyzed to determine $\mathrm{U}-\mathrm{Pb}$ ages. The analysis protocols followed the standard procedures for $\mathrm{U}-\mathrm{Pb}$ zir- con analysis used by the UCLA CAMECA ims 1270 ion probe facility [38]. $\mathrm{U}-\mathrm{Pb}$ ages are calculated after a ${ }^{204} \mathrm{~Pb}$-based common $\mathrm{Pb}$ correction for surface contamination by local anthropogenic sources [39].

\subsection{Ion microprobe oxygen isotopic measurements}

Oxygen isotope measurements were made with the CAMECA ims1270 ion microprobe at UCLA. Previously analyzed zircons were regrinded and repolished to remove the surface layer contaminated from the ${ }^{16} \mathrm{O}^{-}$ ion beam during the $\mathrm{U}-\mathrm{Th}-\mathrm{Pb}$ analyses, and recoated with Au. A $\sim 15 \times 20 \mu \mathrm{m}$ oval $\mathrm{Cs}^{+}$primary beam with a primary intensity of $\sim 3 \mathrm{nA}$ was focused onto the sample surface, and a normal incidence electron gun was used for charge compensation. Secondary ions of ${ }^{16} \mathrm{O}^{-}$and ${ }^{18} \mathrm{O}^{-}$were simultaneously collected in two Faraday cups (FC) and their intensities were corrected for FC relative yields and backgrounds. Instrumental mass fractionation (IMF) was calibrated from bracketing measurements of 91500 and Pacoima Canyon zircon standards [40,41]. 
For most sessions, both standards were present on the same mount and were cross-checked. Systematic deviations in IMF were absent, suggesting that matrix effects resulting from compositional variations (e.g., $\mathrm{HfO}_{2}$ abundance) are insignificant for low energy oxygen isotope analysis at the level of analytical precision. The standard deviation of replicate analyses of the bracketing zircon standards during individual sessions is between 0.16 and $0.43 \%$, and we adopt the external reproducibility of standards in each session as an estimate for the uncertainty of unknown $\delta^{18} \mathrm{O}$.

\subsection{Ion microprobe trace element measurements}

After completion of $\mathrm{U}-\mathrm{Th}-\mathrm{Pb}-\mathrm{O}$ analyses, we repolished and Au-recoated selected zircons for analyzing their REE, Ti, and Hf concentrations. In a first set of measurements, the UCLA CAMECA ims1270 ion microprobe was set-up for energy-filtering to suppress oxide interferences on heavy REE (moderate mass resolution of $\sim 1500 ;-110-80 \mathrm{eV}$ energy offset; $\sim 20 \mathrm{nA}$ ${ }^{16} \mathrm{O}^{-}$; $30 \mu \mathrm{m}$ spot size). REE and Ti intensities were normalized to ${ }^{30} \mathrm{Si}^{+}$and corrected for interfering oxides. Relative sensitivities were calculated from NIST SRM 610 glass [42]. While we found good agreement for REE concentrations compared to published values for 91500 , the measured $\mathrm{Ti}$ concentrations appear to be systematically low by $\sim 10 \%$. We attribute these low concentrations to the difference between ion yields from NIST SRM 610 glass and zircon, and apply a correction factor derived from the measured ${ }^{49} \mathrm{Ti}^{+}{ }^{\beta 0} \mathrm{Si}^{+}$divided by the atomic Ti/Si ratio of SL-13 zircon (6.8 ppm Ti; Harrison, pers. comm.).

In a second session, Ti was analyzed without energy filtering $\left(\sim 5 \mathrm{nA}{ }^{16} \mathrm{O}^{-}\right.$beam; spot size $\left.\sim 20 \mu \mathrm{m}\right)$ whereby the $\mathrm{Ti} / \mathrm{Zr}$ relative sensitivity was calibrated by ${ }^{49} \mathrm{Ti}^{+} / 96 \mathrm{Zr}^{2+}$ measurements of SL-13. In this mode, we applied high-mass resolution $(\sim 6000)$ to resolve the ${ }^{48} \mathrm{TiH}^{+}$hydride interference on ${ }^{49} \mathrm{Ti}^{+} .{ }^{57} \mathrm{Fe}^{+} /{ }^{96} \mathrm{Zr}^{2+}$ was monitored for beam overlap on glass or $\mathrm{Fe}-\mathrm{Ti}$ oxide inclusions, which potentially could overwhelm the $\mathrm{Ti}$ signal derived from zircon. Both techniques, energyfiltering and high-mass resolution, yielded consistent results for 91500 as a secondary standard $(\sim 5 \mathrm{ppm} \mathrm{Ti}$ compared to the 3-6 ppm range in [43]; see also Data Repository Table 3).

\section{Results}

\section{1. ${ }^{238} \mathrm{U}^{230}$ Th zircon ages}

Zircons from Salton Buttes rhyolites are $\sim 100$ $150 \mu \mathrm{m}$ long. BSE and CL imaging reveals concentric oscillatory zoning in most zircons, but some grains (e.g., SB0402 2; Fig. 2A) show patchy CL signals that are similar to those observed in zircons from the granophyre xenoliths (see below). $\left({ }^{238} \mathrm{U}\right) /\left({ }^{232} \mathrm{Th}\right)$ values for Salton Buttes rhyolite zircons range between $\sim 3$ and 6 , which is consistent with the expected zircon-melt fractionation of $5-6$ [44]) and bulk rock $\left({ }^{238} \mathrm{U}\right) /\left({ }^{232} \mathrm{Th}\right)$ of $\sim 0.95$ [27]. Zircons from Obsidian Butte and Red Island are indistinguishable, and $\left({ }^{238} \mathrm{U}\right) /\left({ }^{232} \mathrm{Th}\right)$ and $\left({ }^{230} \mathrm{Th}\right) /$ $\left({ }^{232} \mathrm{Th}\right)$ ratios of 17 grains closely overlap with the smaller set $(n=7)$ of $\mathrm{U}-\mathrm{Th}$ zircon analyses previously reported for Red Island [45]. The relatively large spread of $\left({ }^{238} \mathrm{U}\right) /\left({ }^{232} \mathrm{Th}\right)$ allows zircon internal isochrons to be calculated. Salton Buttes zircons yield an average isochron age of $\sim 12 \mathrm{ka}$, overlaping within uncertainty with the Red Island age ( $\sim 16 \mathrm{ka}$; [45]). However, the large MSWD (5.3) indicates excess variation in the UTh ratios beyond analytical uncertainty. To quantify the range of ages, we plotted a wedge-shaped field in Fig. 3,

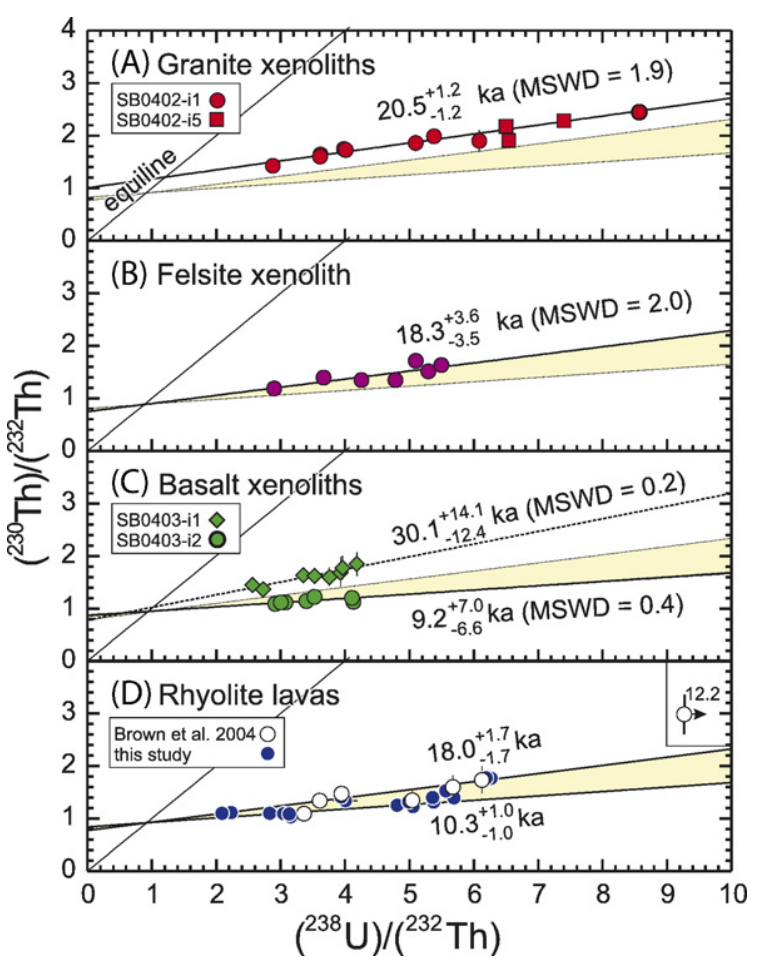

Fig. 3. Isochron diagram plotting $\left({ }^{230} \mathrm{Th}\right) /\left({ }^{232} \mathrm{Th}\right)$ against $\left({ }^{238} \mathrm{U}\right) /$ $\left({ }^{232} \mathrm{Th}\right)$ for Salton Buttes zircons. Error weighted-regressions are plotted with calculated ages and uncertainties $(1 \sigma)$. Wedge in A-D is the "sphenochron" for zircons from Salton Buttes rhyolite lavas with upper and lower age boundaries calculated applying the Sambridge and Compston [47] mixing algorithm assuming a bimodal age population. The calculated ratio of younger over older zircon grains in this model is $\sim 2: 1$. Note that the results in D agree excellently with data from Brown et al. [45] for Red Island zircons. 
analogous to sphenochrons in ${ }^{40} \mathrm{Ar} /{ }^{39} \mathrm{Ar}$ geochronology (e.g., [46]). The upper (18.0 $\pm 1.7 \mathrm{ka})$ and lower (10.3 \pm $1.0 \mathrm{ka})$ sphenochron boundaries were determined by fitting a mixing algorithm to the U-Th zircon model age distribution ([47]). These model ages were calculated from the slope of two-point isochrons defined by zircon and model equilibrium melt compositions (the apex of the sphenochron). The initial $\left({ }^{230} \mathrm{Th}\right) /\left({ }^{232} \mathrm{Th}\right)_{0}=0.92 \pm$ 0.04 is determined from the intersection of the best-fit line through all rhyolite zircon results with the equiline [48], and is similar to values for other rhyolites from young rift settings (e.g., [49,50]). Two zircons from Obsidian Butte plotting on the equiline yield ${ }^{207} \mathrm{~Pb} /{ }^{206} \mathrm{~Pb}$ ages of $1372 \pm 60$ and $1535 \pm 38 \mathrm{Ma}$, an age population previously unrecognized by Brown et al. [45] who reported a single pre-Quaternary xenocryst of Jurassic age.

Zircons in granophyre xenoliths (SB0402-i1 and SB0402-i2) are interstitial and up to a few 100's $\mu \mathrm{m}$ in size. They are turbid in transmitted light due to abundant mineral inclusions and vesicles, and their CL activity is generally low and is irregularly patchy (Fig. 2D-F). Energy-dispersive X-ray analysis revealed that the some inclusions are Th-rich monazite. Granophyre zircons define a single isochron $(20.5 \pm 1.2 \mathrm{ka}, \mathrm{MSWD}=1.9$; Fig. 3A) with an initial $\left({ }^{230} \mathrm{Th}\right) /\left({ }^{232} \mathrm{Th}\right)_{0}=1.21 \pm 0.04$ somewhat higher than for rhyolite lavas.

Felsite xenolith zircons are similar in size and CL patterns to the rhyolite lava zircons. They define an isochron with $\left({ }^{230} \mathrm{Th}\right) /\left({ }^{232} \mathrm{Th}\right)_{0}=0.88 \pm 0.11(\mathrm{MSWD}=$ 2.0; Fig. 3B) indistinguishable from the older zircon population in the Salton Buttes lavas.

Basaltic xenoliths contain zircons with CL zonation similar to rhyolite zircons (Fig. 2B-C). Basaltic xenolith SB0403-i1 yields a U-Th zircon isochron age of $30.0_{-12.4}^{+14.1} \mathrm{ka}(\mathrm{MSWD}=0.2)$, whereas SB0403-i2 zircons define an isochron age of $9.2_{-6.6}^{+7.0} \mathrm{ka}(\mathrm{MSWD}=0.4$; Fig. 3C). As is the case for the other samples, both isochrons intersect the equiline near $\left({ }^{238} \mathrm{U}\right) /\left({ }^{232} \mathrm{Th}\right) \sim 1$ and yield initial $\left({ }^{230} \mathrm{Th}\right) /\left({ }^{232} \mathrm{Th}\right)_{0}$ of $1.03 \pm 0.27$ and $0.95 \pm 0.15$, respectively, overlapping within uncertainty with the rhyolite lavas. Finally, we note the absence of pre-Quaternary zircons in any of the xenolith samples.

\subsection{Oxygen isotopes}

The $\delta^{18} \mathrm{O}_{\text {zircon }}$ values for Salton Buttes lavas, felsite and basaltic xenoliths are remarkably similar and fall near or below the lower limit for mantle-derived zircon ([51] ; Fig. 4; Table 1). Pre-Quaternary zircons from the lavas and detrital zircon xenocryst samples from drill

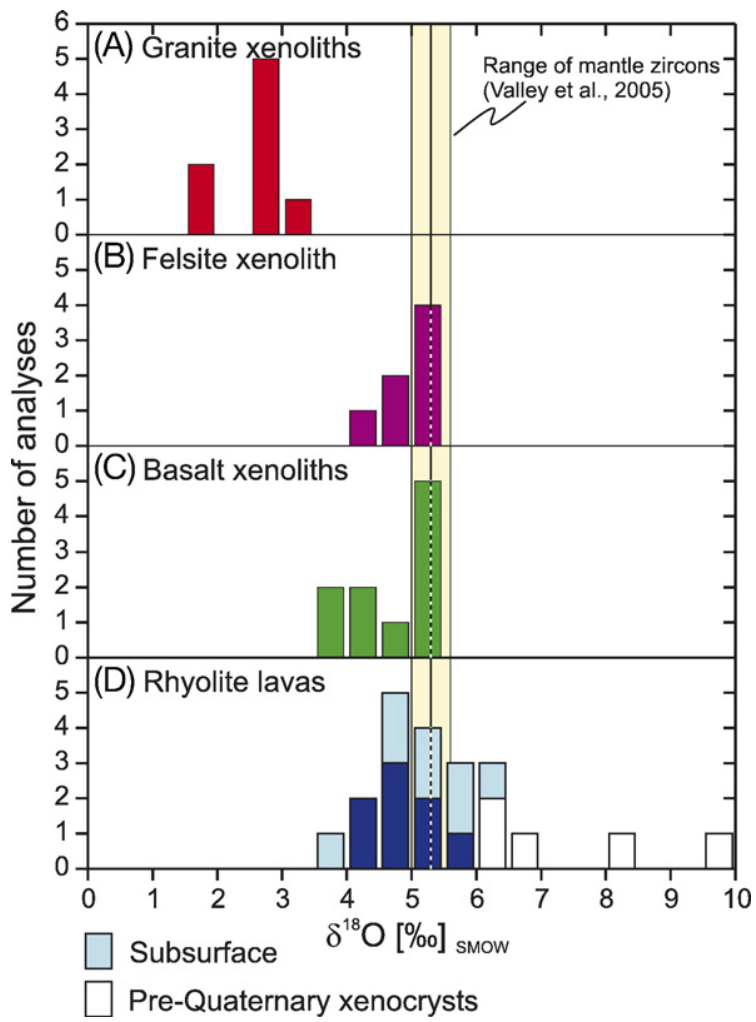

Fig. 4. Histograms for ion microprobe zircon $\delta^{18} \mathrm{O}$ results with errorweighted averages and standard errors (scaled by the square-root of the MSWD if MSWD>1). Shaded field indicates range of $\delta^{18} \mathrm{O}_{\text {zircon }}$ in equilibrium with pristine mantle-derived melts $(+5.3 \pm 0.3 \%$; [51]).

cuttings (Data Repository Table 4), by contrast, have higher $\delta^{18} \mathrm{O}_{\text {zircon }}$ between +6.0 and $+9.7 \%$, typical for zircon from crustal silicic rocks in the western United States (e.g., [52]). We calculated average $\delta^{18} \mathrm{O}$ values for samples where zircon populations appear homogeneous (Fig. 4): felsite xenolith $\delta^{18} \mathrm{O}_{\text {zircon }}=+4.8 \pm 0.2 \%$ $(\mathrm{MSWD}=0.6)$, basaltic xenolith SB0403-i1 $\delta^{18} \mathrm{O}_{\text {zircon }}=$ $+3.8 \pm 0.2 \%$ (MSWD $=0.9)$, and basaltic xenolith SB0403-i $2 \delta^{18} \mathrm{O}_{\text {zircon }}=+5.0 \pm 0.2 \%$ o $(\mathrm{MSWD}=0.2)$. For the rhyolites, we obtain an average $\delta^{18} \mathrm{O}_{\text {zircon }}=+4.8 \pm$ $0.2 \%$ with an elevated $\mathrm{MSWD}=2.7$ that suggests heterogeneity in the population. This is consistent with the heterogeneity of $\mathrm{U}-\mathrm{Th}$ age results. Zircons from granophyre xenoliths have the lowest $\delta^{18} \mathrm{O}_{\text {zircon }}$ values and also show the largest spread $\left(\delta^{18} \mathrm{O}_{\text {zircon }}=+1.5-\right.$ $+3.0 \%$ ). Replicate analyses on a large granophyre zircon (SB0402-1 grain 1) after regrinding and repolishing agree closely, which suggests that oxygen isotopic heterogeneity is unrelated to beam overlap with inclusions or analytical artifacts (Table 1). In Fig. 4, we also plotted $\delta^{18} \mathrm{O}_{\text {zircon }}$ for subsurface rhyolites (Data Repository Table 2). Overall, $\delta^{18} \mathrm{O}_{\text {zircon }}$ for subsurface rhyolites overlaps closely with Salton Buttes zircon. 
Table 1

$\mathrm{U}-\mathrm{Th}$ results

\begin{tabular}{|c|c|c|c|c|c|c|}
\hline Grain & Spot & $\left({ }^{230} \mathrm{Th}\right) /\left({ }^{232} \mathrm{Th}\right)$ & $\pm 1 \sigma$ & $\left({ }^{238} \mathrm{U}\right) /\left({ }^{232} \mathrm{Th}\right)$ & $\pm 1 \sigma$ & $\begin{array}{l}\mathrm{U} \\
(\mathrm{ppm})\end{array}$ \\
\hline \multicolumn{7}{|c|}{ 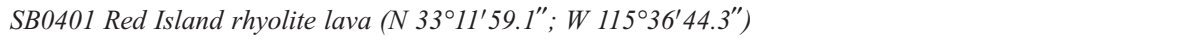 } \\
\hline 1 & 1 & 1.09 & 0.02 & 3.14 & 0.06 & 4442 \\
\hline 5 & 1 & 1.42 & 0.05 & 3.94 & 0.02 & 960 \\
\hline 6 & 1 & 1.52 & 0.10 & 5.56 & 0.05 & 408 \\
\hline 7 & 1 & 1.10 & 0.02 & 2.83 & 0.01 & 3551 \\
\hline 8 & 1 & 1.40 & 0.11 & 5.36 & 0.11 & 522 \\
\hline 10 & 1 & 1.32 & 0.06 & 5.37 & 0.04 & 788 \\
\hline
\end{tabular}

SB0402 Obsidian Butte rhyolite lava (N 3310'14.6"; W $\left.115^{\circ} 38^{\prime} 03.1^{\prime \prime}\right)$

$\begin{array}{lllll}1 & 1 & 1.34 & 0.06 & 4.01 \\ 2 & 1 & 1.77 & 0.07 & 6.19 \\ 7 & 1 & 1.09 & 0.02 & 3.04 \\ 8 & 1 & 1.77 & 0.12 & 6.27 \\ 8 & 2 & - & - & - \\ 9 & 1 & 1.22 & 0.06 & 5.05 \\ 10 & 1 & 1.10 & 0.02 & 2.09 \\ 11 & 1 & 1.11 & 0.04 & 2.23 \\ 12 & 1 & 1.03 & 0.04 & 3.16 \\ 13 & 1 & 1.32 & 0.08 & 4.99 \\ 15 & 1 & 1.39 & 0.14 & 5.69 \\ 16 & 1 & 1.25 & 0.10 & 4.81 \\ 17^{\star} & 1 & 4.70 & 0.36 & 4.52 \\ 14^{\star} & 1 & 4.68 & 0.59 & 4.37\end{array}$

SB0402-il Obsidian Butte granophyre xenolith

\begin{tabular}{|c|c|c|c|c|c|c|c|c|}
\hline 1 & 1 & 1.90 & 0.06 & 6.08 & 0.21 & 2802 & +2.9 & 0.2 \\
\hline 1 & 2 & - & - & - & - & - & +2.7 & 0.4 \\
\hline 1 & $1 \dagger$ & - & - & - & - & - & +3.0 & 0.2 \\
\hline 1 & $2 \dagger$ & - & - & - & - & - & +2.9 & 0.4 \\
\hline 5 & 1 & 2.45 & 0.06 & 8.57 & 0.10 & 3913 & +2.9 & 0.2 \\
\hline 1 & 2 & 1.86 & 0.05 & 5.10 & 0.16 & 2967 & - & - \\
\hline 2 & 1 & 1.99 & 0.04 & 5.38 & 0.06 & 2499 & +2.7 & 0.2 \\
\hline 3 & 1 & 1.64 & 0.03 & 3.62 & 0.06 & 2601 & +1.5 & 0.2 \\
\hline 3 & 2 & 1.60 & 0.04 & 3.61 & 0.02 & 1537 & +1.9 & 0.2 \\
\hline 4 & 1 & 1.43 & 0.04 & 2.88 & 0.02 & 2189 & +2.9 & 0.2 \\
\hline 6 & 1 & 1.75 & 0.05 & 3.98 & 0.03 & 1357 & - & - \\
\hline 11 & 1 & 1.73 & 0.04 & 4.01 & 0.10 & 3424 & - & - \\
\hline \multicolumn{9}{|c|}{ SB0402-i5 Obsidian Butte granophyre xenolith } \\
\hline 2 & 1 & 2.18 & 0.06 & 6.49 & 0.08 & 2273 & - & - \\
\hline 2 & 2 & 2.28 & 0.06 & 7.40 & 0.05 & 2875 & - & - \\
\hline 1 & 1 & 1.92 & 0.09 & 6.55 & 0.16 & 1994 & - & - \\
\hline \multicolumn{9}{|c|}{ SB0403-i1 Obsidian Butte basaltic xenolith } \\
\hline 11 & 1 & 1.15 & 0.04 & 3.40 & 0.03 & 1508 & +3.3 & 0.4 \\
\hline 12 & 1 & 1.13 & 0.10 & 4.13 & 0.02 & 295 & +3.7 & 0.4 \\
\hline 12 & 2 & - & - & - & - & - & +4.4 & 0.4 \\
\hline 13 & 1 & 1.12 & 0.04 & 3.07 & 0.01 & 1038 & +3.8 & 0.4 \\
\hline 13 & 2 & - & - & - & - & - & +4.0 & 0.4 \\
\hline 1 & 1 & 1.09 & 0.05 & 2.92 & 0.01 & 2627 & - & - \\
\hline 6 & 1 & 1.20 & 0.08 & 4.11 & 0.02 & 2153 & - & - \\
\hline 7 & 1 & 1.12 & 0.06 & 3.00 & 0.01 & 1547 & - & - \\
\hline 3 & 1 & 1.23 & 0.07 & 3.52 & 0.01 & 1909 & - & - \\
\hline \multicolumn{9}{|c|}{ SB0403-i2 Obsidian Butte basaltic xenolith } \\
\hline 2 & 1 & 1.45 & 0.10 & 2.57 & 0.01 & 252 & +5.1 & 0.4 \\
\hline 4 & 1 & 1.64 & 0.14 & 3.36 & 0.01 & 177 & +5.0 & 0.4 \\
\hline
\end{tabular}


Table 1 (continued)

\begin{tabular}{|c|c|c|c|c|c|c|c|c|}
\hline Grain & Spot & $\left({ }^{230} \mathrm{Th}\right) /\left({ }^{232} \mathrm{Th}\right)$ & $\pm 1 \sigma$ & $\left({ }^{238} \mathrm{U}\right) /\left({ }^{232} \mathrm{Th}\right)$ & $\pm 1 \sigma$ & $\begin{array}{l}\mathrm{U} \\
\text { (ppm) }\end{array}$ & $\begin{array}{l}\delta^{18} \mathrm{O}(\mathrm{SMOW}) \\
(\% \mathrm{o})\end{array}$ & $\pm 1 \sigma^{\star \star}$ \\
\hline \multicolumn{9}{|c|}{ SB0403-i2 Obsidian Butte basaltic xenolith } \\
\hline 5 & 1 & 1.61 & 0.17 & 3.75 & 0.01 & 149 & +4.9 & 0.4 \\
\hline 6 & 1 & 1.63 & 0.11 & 3.53 & 0.01 & 203 & +5.2 & 0.4 \\
\hline 1 & 1 & 1.37 & 0.10 & 2.73 & 0.01 & 275 & +4.8 & 0.4 \\
\hline 4 & 2 & 1.85 & 0.23 & 4.18 & 0.02 & 148 & - & - \\
\hline 5 & 2 & 1.78 & 0.22 & 3.96 & 0.01 & 247 & - & - \\
\hline 6 & 2 & 1.70 & 0.29 & 3.93 & 0.01 & 116 & - & - \\
\hline \multicolumn{9}{|c|}{ SB0401-i1 Red Island"felsite" xenolith } \\
\hline 3 & 1 & 1.35 & 0.07 & 4.78 & 0.01 & 635 & +4.9 & 0.4 \\
\hline 7 & 1 & 1.52 & 0.10 & 5.30 & 0.01 & 385 & +5.1 & 0.4 \\
\hline 9 & 1 & 1.63 & 0.10 & 5.49 & 0.01 & 461 & +5.0 & 0.4 \\
\hline 1 & 1 & 1.19 & 0.04 & 2.90 & 0.03 & 2512 & +4.1 & 0.4 \\
\hline 2 & 1 & 1.34 & 0.09 & 4.26 & 0.03 & 561 & +4.7 & 0.4 \\
\hline 15 & 1 & 1.71 & 0.09 & 5.10 & 0.01 & 487 & +4.7 & 0.4 \\
\hline 10 & 1 & 1.39 & 0.07 & 3.67 & 0.02 & 775 & +5.1 & 0.4 \\
\hline
\end{tabular}

Activity calculations using decay constants: $\lambda_{230}: 9.1577 \times 10^{-6} \mathrm{a}^{-1} ; \lambda_{232}: 4.9475 \times 10^{-11} \mathrm{a}^{-1} ; \lambda_{238}: 1.55125 \times 10^{-10} \mathrm{a}^{-1}$.

${ }^{\star} \mathrm{U}-\mathrm{Pb}$ results for grain 17 :

${ }^{206} \mathrm{~Pb}^{\star} p^{238} \mathrm{U}=0.259 \pm 0.012 ;{ }^{207} \mathrm{~Pb}{ }^{\star} / 235 \mathrm{U}=3.40 \pm 0.15 ;{ }^{207} \mathrm{~Pb}^{\star}{ }^{206} \mathrm{~Pb}^{\star}=0.0953 \pm 0.0019 ;{ }^{204} \mathrm{~Pb} /{ }^{206} \mathrm{~Pb}=0.00004 \pm 0.00003$; concordia error correlation coefficient $=0.90$.

${ }^{\star} \mathrm{U}-\mathrm{Pb}$ results for grain 14 :

${ }^{206} \mathrm{~Pb}^{\star} p^{238} \mathrm{U}=0.261 \pm 0.036 ;{ }^{207} \mathrm{~Pb}{ }^{\star}{ }^{235} \mathrm{U}=3.15 \pm 0.47 ;{ }^{207} \mathrm{~Pb}{ }^{\star} /{ }^{206} \mathrm{~Pb}^{\star}=0.0876 \pm 0.0027 ;{ }^{204} \mathrm{~Pb} /{ }^{206} \mathrm{~Pb}=0.00012 \pm 0.00012$; concordia error correlation coefficient $=0.98$.

$\star \star 1 \sigma$ error estimated from external reproducibility of standard zircon ( 1 standard deviation). The following instrumental mass fractionations (IMF) and $\delta^{18} \mathrm{O}$ values for secondary standards were obtained for individual sessions:

2/28/2005: IMF (Pacoima) $=1.0001 \pm 0.00038 ; n=13$.

3/3/2005: IMF (Pacoima) $=1.0009 \pm 0.00030 ; n=16 ; 91500=+10.05 \pm 0.16 ; n=10$.

$7 / 1 / 2005$ : IMF (Pacoima) $=1.0018 \pm 0.00025 ; n=6 ; 91500=+9.76 \pm 0.27 ; n=6$.

2/14/2005: $\operatorname{IMF}(91500)=0.9995 \pm 0.00043 ; n=12 ;$ Pacoima $=+5.88 \pm 0.33 ; n=5$.

Published $\delta^{18} \mathrm{O}$ values: Pacoima $=+5.7 \%$ [43]; $91500=+9.86 \%$ [42].

$\dagger$ Replicate analyses after repolishing.

\subsection{REE and Ti concentrations}

Selected zircons from the lavas and granophyric xenoliths were analyzed for REE concentrations. The unusual "spongy" textures of granophyre zircons suggest crystallization from a volatile-rich melt or fluid. Fig. 5 displays chondrite-normalized REE patterns for zircons from rhyolite and basaltic xenoliths with oscillatory CL zonations compared to two patchy CL zoned zircons from granophyre xenoliths. Granophyre zircons are strongly LREE enriched compared to zircons from the rhyolitic lavas, with values equal to or exceeding published examples of hydrothermal zircon [53]. Positive Ce anomalies are weak or absent in granophyre zircon. Based on our BSE and CL imaging, we interpret the high LREE abundances and variability to result in part from beam overlap with small $(<5 \mu \mathrm{m})$ monazite inclusions within the zircons. It is difficult to evaluate the presence of such inclusions in published examples of LREE-enriched hydrothermal zircon due to the lack of BSE images (cf. [53]).
Elevated $\mathrm{HfO}_{2}$ concentrations are yet another characteristic of hydrothermal zircon [53]. We find that $\mathrm{HfO}_{2}$ in granophyre zircons ( $2.0 \mathrm{wt} . \%)$ is higher than in zircons from lavas (1.4 wt.\%). Elevated $\mathrm{HfO}_{2}$ is clearly unaffected by monazite inclusions, and therefore supports textural evidence for a hydrothermal origin of the granophyre zircons (Data Repository Table 3).

Ti concentrations for 12 analyzed zircons range between 4 and 47 ppm (Data Repository Table 3). In many instances, zircon sample ${ }^{57} \mathrm{Fe} /{ }^{96} \mathrm{Zr}^{2+}$ ratios were elevated compared to the ratios measured on zircon standards SL-13 and 91500. Because the reason for this is unclear, we opt for a cautionary approach and exclude all data with ${ }^{57} \mathrm{Fe} /{ }^{96} \mathrm{Zr}^{2+}$ higher than the standards in order to avoid erroneous results resulting from potential beam overlap with inclusions such as mafic oxides or glass. By this rationale, we also exclude several high- ${ }^{57} \mathrm{Fe}^{96} \mathrm{Zr}^{2+}$ analyses where Ti concentrations appear to be "normal" and without evidence for beam overlap with inclusions (Data Repository Table 4). 


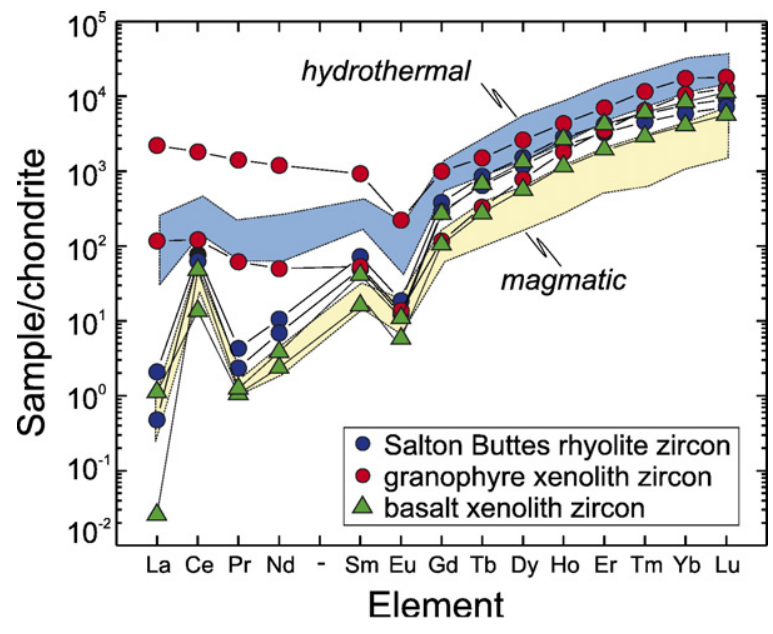

Fig. 5. Chondrite-normalized REE abundances in zircon from ion microprobe measurements of zircon from rhyolite lava, basaltic xenolith, and granophyre. Fields for magmatic and hydrothermal zircon from [53] are shown for comparison. Note large light REE (LREE) variations in zircon from granophyre xenolith that is attributed to the presence of Th and LREE enriched mineral inclusions (see Fig. 2E).

Ti concentrations in zircon vary with crystallization temperatures, which can be calculated if the Ti activity ( $a$ $\left.\left[\mathrm{TiO}_{2}\right]\right)$ of the melt is known [43]. For rutile-saturated melts $a\left[\mathrm{TiO}_{2}\right]=1$, but when rutile is absent as in the case of the Salton Buttes rocks, $a\left[\mathrm{TiO}_{2}\right]$ in the melt will reduce to values typically between $0.5-1$ [43]. Temperatures calculated with $a\left[\mathrm{TiO}_{2}\right]=1$ (rhyolite lavas $=680^{\circ}$ $710^{\circ} \mathrm{C}$; felsite xenolith $=690^{\circ} \mathrm{C}$; granophyre $=720^{\circ}$ $730^{\circ} \mathrm{C}$; basalt xenolith $=770^{\circ} \mathrm{C}$; Data Repository Table 4 need to be adjusted by $\sim 50^{\circ}-65{ }^{\circ} \mathrm{C}$ to higher temperatures, if $a\left[\mathrm{TiO}_{2}\right]=0.5$ [43]. For comparison, zircon saturation temperatures [54] based on wholerock zirconium concentrations for the Salton Buttes rhyolites [27] are $840{ }^{\circ} \mathrm{C}$.

\section{Discussion}

\subsection{Zircon ages in rhyolite lavas and xenoliths and implications for their origins}

The geochemistry and age information from zircon is a proxy for the compositional and thermal state of a melt at the time of zircon crystallization. This is because of the comparatively slow diffusion of trace components and oxygen in zircon at subsolidus temperatures (e.g., [13]). In the case of Salton Buttes rhyolites and xenoliths, U-Th zircon ages between $\sim 30$ and 9 ka estimate the duration of magmatism in the Salton Trough much more precisely than previous $\mathrm{K}-\mathrm{Ar}$ or obsidian rind hydration ages. Specifically, U-Th zircon ages for rhyolites and xenoliths require that Salton Buttes volcanism is at most early Holocene in age. The $10.3 \pm$ $1.0 \mathrm{ka} \mathrm{U}-\mathrm{Th}$ age for the younger zircon population in the lavas overlaps within uncertainty with the oldest obsidian hydration date of $8.4 \mathrm{ka}$ [33], suggesting that zircon crystallization occurred in the magma until shortly before the eruption. The presence of older $\sim 18$ ka zircons could result from (1) protracted zircon crystallization over several 1000 years or (2) recycling from pre-existing zircon bearing rocks. While either scenario is consistent with our data, the discrete $\sim 18 \mathrm{ka}$ zircon population in the felsite xenolith suggests that zircon growth may have been episodic and occurred during an earlier, previously unrecognized event of effusive or hypabyssal rhyolitic magmatism.

Salton Buttes granophyre xenoliths are among the youngest dated granitic rocks on Earth (cf. [55], [48]), and their tightly constrained U-Th zircon ages indicate rapid crystallization within a few $1000 \mathrm{yr}$. The presence of zircon in basaltic xenoliths is remarkable. Based on textures and mineralogy, the basaltic xenoliths appear highly altered and are clearly not pristine basalts or microgabbro cumulates. Zircons are located within plagioclase-rich domains in the basaltic xenoliths and have elevated $\mathrm{U}$ contents and low $\delta^{18} \mathrm{O}$ overlapping the range of rhyolite zircons (Table 1). This indicates crystallization from an evolved silicic melt. Based on sub-mantle $\delta^{18} \mathrm{O}_{\text {zircon }}$ values, we rule out fractional crystallization of MORB-type basaltic magma, and instead favor partial melting of hydrothermally altered basalts as the source of the rhyolites (see discussion below). Even accounting for uncertainties in the activity of $\mathrm{TiO}_{2}$ in the melt, Ti-in-zircon thermometry suggests remelting at temperatures between $\sim 770$ and $835^{\circ} \mathrm{C}$. Based on different $\mathrm{U}-\mathrm{Th}$ zircon ages of two basaltic xenoliths, at least two remelting episodes at $\sim 30 \mathrm{ka}$ and $\sim 9$ ka are likely. These ages are at odds with previous $\mathrm{K}-\mathrm{Ar}$ age dates for basaltic xenoliths, because heating above the solidus temperature of hydrous basalt is expected to reset $\mathrm{K}-\mathrm{Ar}$ parent-daughter relations. A direct comparison between our $\mathrm{U}-\mathrm{Th}$ zircon and published $\mathrm{K}-\mathrm{Ar}$ ages, however, is impossible because different xenoliths were studied. Overall, U-Th zircon evidence for Late Pleistocene-Holocene magmatic pulses in the SSGF subsurface is consistent with evidence for a young hydrothermal system from thermal models [19], detrital K-feldspar thermal histories [20], and U-series disequilibrium in geothermal brines [21].

Finally, our view on the significance of pre-Quaternary zircons in the lavas is different from Brown et al [45] who interpreted the presence of a single Jurassic zircon as evidence for a significant role of sedimentary or granite- 
type basement rocks in the generation of these magmas. Even though we encountered two additional preQuaternary zircons of Proterozoic age in our samples, we interpret these older crystals as detrital grains that were incorporated into the rhyolite due to disintegration of soft mudstone and sandstone during the eruption, instead of representing xenocrysts inherited from the source. This view is based on the ubiquity of sedimentary fragments in the lavas, commonly smeared out and intermingled with the obsidian (e.g., [11]). The absence of visible overgrowth textures around pre-Quaternary zircons in the rhyolites and the lack of pre-Quaternary zircons in granophyre xenoliths further support our interpretation that these grains were incorporated at or near the time of eruption. Most importantly, oxygen isotopic compositions of Quaternary zircons unequivocally rule out anatexis of sedimentary or basement granitoids as the source for Salton Buttes rhyolites (see below).

\section{2. $\delta^{18} \mathrm{O}$ depletion in rhyolite source}

Magmatic zircon records the oxygen isotope composition of its host melt which can be calculated by applying empirically calibrated isotopic fractionation factors (summarized in [56]). For the approximate crystallization temperature at $800{ }^{\circ} \mathrm{C}$, the isotopic fractionation $\alpha$ between zircon and rhyolite (expressed as $1000 \times \ln \alpha=1.0016$; [56]) yields a $\delta^{18} \mathrm{O}_{\text {melt }}$ value of $+6.4 \%$ o for Salton Buttes lavas (Fig. 6). This value overlaps within uncertainty with $\delta^{18} \mathrm{O}=+6.1 \%$ for whole-rock Salton Buttes obsidian (Fig. 6; [25]). The equilibrium between $\delta^{18} \mathrm{O}_{\text {zircon }}$ and $\delta^{18} \mathrm{O}_{\text {melt }}$ in lavas (from whole-rock $\delta^{18} \mathrm{O}$ ) demonstrates that secondary alteration of the glass cannot explain low $\delta^{18} \mathrm{O}$ values in the bulk lavas, which are clearly distinct from typical compositions of continental basement in the Western United States (e.g., [52]). Because zircons in basaltic xenoliths occur in plagioclase-rich domains with interstitial rhyolite glass present (e.g., [11]), we use the same zircon-rhyolite isotopic fractionation factor and calculate $\delta^{18} \mathrm{O}_{\text {melt }}$ compositions between +5.4 and $+6.6 \%$. From oxygen isotope compositions, the $\mathrm{Sr}$ and $\mathrm{Nd}$ isotopic similarity of Salton Buttes rhyolites and basaltic xenoliths [12], and textural evidence for partial melting in basaltic xenoliths, we thus infer a dominantly basaltic source for the Salton Buttes rhyolites.

To further evaluate the oxygen isotopic composition of the basaltic source, we modeled equilibrium meltresidue oxygen isotope fractionation for a tholeiitic basalt bulk composition. For this model, we combined normative phase abundances from whole-rock composi-

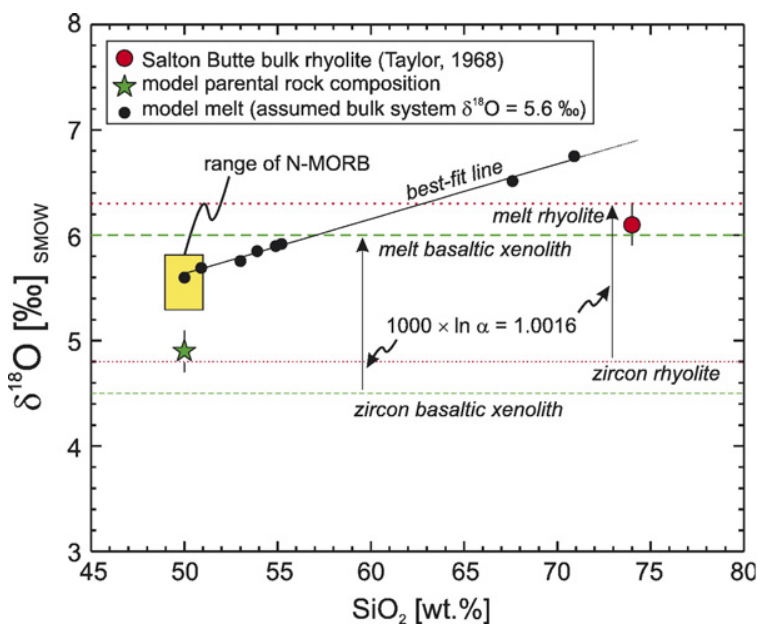

Fig. 6. Oxygen isotopic composition vs. $\mathrm{SiO}_{2}$ for MORB [59] and Salton Buttes rhyolite whole-rock [52] and zircon (indicated by horizontal lines for average values of rhyolite lavas and basaltic xenoliths; this study). The best-fit equation for model $\delta^{18} \mathrm{O}_{\text {melt }}$ evolution for closed-system equilibrium crystallization of uncontaminated MORB [57] is: $\delta^{18} \mathrm{O}_{\text {melt }}=(0.052 \pm 0.0014) \times \mathrm{SiO}_{2}+(3.03 \pm$ $0.08)$. Note that $\delta^{18} \mathrm{O}_{\text {melt }}$ exceeds Salton Buttes rhyolite oxygen isotopic compositions for $\mathrm{SiO}_{2}>70 \mathrm{wt} . \%$ by $0.5-1 \%$. Low $\delta^{18} \mathrm{O}_{\text {rock }}$ of the model starting composition compared to pristine MORB [57] implies isotopic exchange with meteoric water in the rhyolite source.

tions and experimentally observed melt-crystal proportions from crystallization experiments of oceanic tholeiite at $p_{\text {total }}=p_{\mathrm{H}_{2} \mathrm{O}}=100 \mathrm{MPa}$ over a temperature range from $\sim 1050{ }^{\circ} \mathrm{C}$ to $925{ }^{\circ} \mathrm{C}$ [57] with experimentally calibrated isotopic fractionation factors (compiled in [58]) to calculate $\delta^{18} \mathrm{O}_{\text {melt }}$ as a function of $\mathrm{SiO}_{2}$ content of the melt (Fig. 6). This model suggests that closed system equilibrium melting or crystallization (melt fraction $<10 \%$ ) of tholeiitic basalt with a bulk composition of $\delta^{18} \mathrm{O}=+5.6 \%$ (e.g., [59]) produces a rhyolite melt with $\mathrm{SiO}_{2}=70$ wt. $\%$ and $\delta^{18} \mathrm{O}_{\text {melt }}=$ $+6.8 \%$. This value for $\delta^{18} \mathrm{O}_{\text {melt }}$ is approximately $0.5 \%$ higher than $\delta^{18} \mathrm{O}_{\text {melt }}$ for Salton Buttes rhyolite inferred from conventional and ion microprobe zircon methods. If experimentally calibrated phase relations are extrapolated to $\mathrm{SiO}_{2}=75 \%, \delta^{18} \mathrm{O}_{\text {melt }}$ exceeds observed compositions for Salton Buttes rhyolites by $\sim 1 \%$ (Fig. 6), which is beyond uncertainties for SIMS and conventional oxygen isotope measurements.

A similar model (using an average ${ }^{18} \mathrm{O}_{\text {zircon }}=+4.5 \%$ from zircon in basaltic xenoliths) suggests that the basaltic source with $\mathrm{SiO}_{2}=50$ wt.\% had an oxygen isotopic composition with $\delta^{18} \mathrm{O}=+4.9 \pm 0.2 \%$, which at the $95 \%$ confidence level is outside the $\delta^{18} \mathrm{O}$ range of uncontaminated MORB basalt [59]. From this model and similar results in Eiler [59], we conclude that evolved melts with $\delta^{18} \mathrm{O}<+6.5 \%$ are "low- $\delta{ }^{18} \mathrm{O}$ " rhyolites if 
their $\mathrm{SiO}_{2}$ is $>70$ wt.\%. Accordingly, the Salton Buttes zircon-crystallizing melts are "low- $\delta{ }^{18} \mathrm{O}$ " type.

We neglected assimilation of granitic basement or sedimentary rocks, but the effects are likely to be small in the light of similar $\mathrm{Nd}$ and $\mathrm{Sr}$ isotopic compositions in Salton Buttes rhyolites and uncontaminated East Pacific Rise MORB basalts [12,30]. In any case, assimilation of crustal rocks will shift rhyolite $\delta^{18} \mathrm{O}$ to higher values, which would imply that our calculated $\delta^{18} \mathrm{O}$ for the basaltic source represent a maximum value. We attribute the low $\delta^{18} \mathrm{O}$ of Salton Buttes rhyolites to oxygen isotopic exchange of their basaltic source rocks with aqueous fluids. In the Salton Trough, surface waters have $\delta^{18} \mathrm{O}$ as low as $-10 \%$ [60]. Low $-\delta^{18} \mathrm{O}$ rhyolites are characteristic of ridge-axis volcanism in Iceland (e.g., [61-63]) and despite the less pronounced low $-\delta^{18} \mathrm{O}$ signature of Salton Trough rhyolites, we hypothesize that a common process links rhyolite genesis in the Salton Trough and Iceland; in other words, remelting of young hydrothermally altered basaltic crust producing rhyolites is common in oceanic and continental rifts. Silicic melt pockets in altered basaltic xenoliths from the Salton Buttes are direct evidence for this process.

The modest ${ }^{18} \mathrm{O}$ depletion of the Salton Buttes rhyolites relative to those from Iceland may be related to their respective tectonic settings. A significant difference between both rifts and their associated hydrothermal systems is the thick sedimentary infill of the Salton Trough that is derived from a proximal continental crustal source. These sediments have high $\delta^{18} \mathrm{O}$ that during reaction with meteoric waters will produce a " $\delta^{18} \mathrm{O}$ shift" resulting in elevated $\delta^{18} \mathrm{O}$ in crustal fluids [60]. As these fluids penetrate and react with basaltic crust at depth, they will impart a moderated "low- $\delta{ }^{18} \mathrm{O}$ " signature on these basalts. A significant implication of the low $\delta^{18} \mathrm{O}$ signature of synrift rhyolites from the Salton Trough is that hydrothermal convection reaches deep into young basaltic crust, efficiently dissipating heat from the magmatic accretion layer.

\subsection{Hydrothermal zircon in granophyre xenoliths and role of fluids}

In the previous discussion, we excluded the strongly ${ }^{18} \mathrm{O}$-depleted zircons from granophyre xenoliths which yield $\delta^{18} \mathrm{O}_{\text {zircon }}$ between +1.5 and $+3.0 \%$. Based on the excellent reproducibility of measurements on the same grains after regrinding and repolishing that removed all traces of previous sputter pits (Table 1), these low $\delta^{18} \mathrm{O}$ values are unrelated to beam overlap with inclusions, domains implanted with ${ }^{16} \mathrm{O}$ from previous ion mi- croprobe analyses, or epoxy. Low $\delta^{18} \mathrm{O}_{\text {zircon }}$ therefore indicates the isotopic influence of surface waters in the zone of granophyre crystallization and may be related to direct precipitation from hydrothermal fluids. This is supported by elevated $\mathrm{HfO}_{2}$ concentrations characteristic for late-stage crystallization involving interstitial aqueous fluid (e.g., [53]). Isotopic fractionation between zircon and aqueous fluid at near-solidus temperatures for a granitic melt $\left(\sim 700^{\circ} \mathrm{C}\right)$ are approximately $-1 \%$, but fractionation factors at these temperatures are poorly calibrated [56]. Despite these uncertainties, $\delta^{18} \mathrm{O}_{\text {zircon }}$ for the granophyres is approximately consistent with geothermal fluid compositions in the $\operatorname{SSGF}\left(\delta^{18} \mathrm{O}=\right.$ $+3 \%$ [60])

The occurrence of granophyres is typically associated with rapid crystallization of undercooled rhyolitic melt [32]. Marsh et al. [64] noticed a close association between peripheral granophyres and basaltic intrusions in Iceland. Similarly, the formation of granophyric granite beneath the Salton Trough can be related to extraction of small-volume partial melts that rapidly chilled and crystallized in the contact to cold wall-rocks, whereby cooling may be facilitated by fluid convection. No direct constraints on the depth of granophyre formation is presently available for the Salton Trough except for their absence in geothermal drill wells up to a depth of $\sim 3 \mathrm{~km}$. Future studies of melt inclusion volatile contents may shed light on this important question.

Synrift lavas and xenoliths from Salton Buttes reveal that the transitional layer between shallow sedimentary fill and deep gabbroic crust [8] comprises an intrusive complex with hydrothermally altered basalts, granitic intrusions that are generated by melting of hydrothermally altered basalts, and recent basaltic recharge that provides the heat for the thermal reprocessing of youthful basaltic crust (Fig. 7). Applying crustal density models $([7,8])$, we predict basaltic magmas stalling at neutral buoyancy levels corresponding to depths between 4 and $12 \mathrm{~km}$ (Fig. 7; cf. [65]). The absence of zircons $>30 \mathrm{ka}$ (except for few sediment-derived xenocrysts) indicates youthful oceanic crust beneath the Salton Buttes with preexisting basement either absent or not significantly contributing to magmatism. From thermal modeling, Lachenbruch et al. [10] argued that high extensions rates equivalent to differential velocities of the North American and Pacific plates $(5 \mathrm{~cm} / \mathrm{a})$ would be unsustainable for the entire 4-5 Ma history of the Salton Trough because localized extension and rapid filling of the extensional gap by basaltic intrusion would trigger massive crustal melting, for which geophysical evidence is lacking [8]. Instead, Lachenbruch et al. [10] argued for distributed extension over a $\sim 150 \mathrm{~km}$ 
(A)

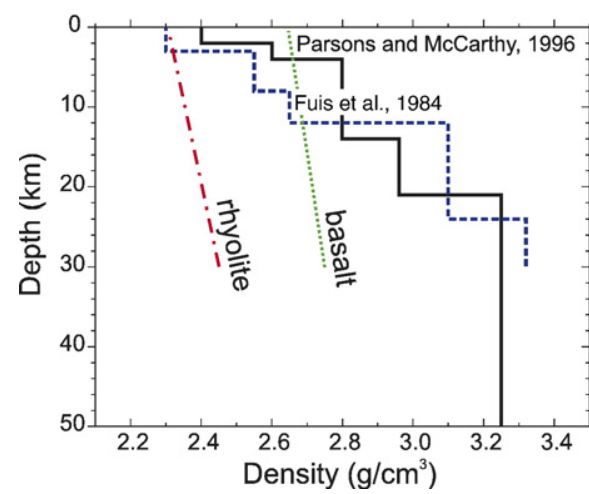

remelting of

(B) hydrothermally

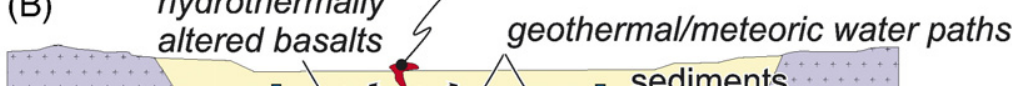

Fig. 7. Seismically derived density models for the Salton Trough [7,8] and calculated [66] magma densities for Salton Buttes rhyolite and MORB basalt (A). Conceptual sketch (B) showing cross-section through Salton Trough crust composed of main basaltic magma body, basaltic satellite intrusions and silicic plutons; vertical axis not to scale. Low $\delta^{18} \mathrm{O}$ of granitic intrusions and rhyolitic lavas requires deep circulation of meteoric water indicated by arrows.

wide spreading region rather than persistent localized spreading in the $\sim 15 \mathrm{~km}$ wide zone of active seismicity in the center of the Salton Trough. Outside the narrow zone that includes the SSGF, however, post-5-Ma synrift magmatic rocks are unknown. Moreover, rhyolites drilled in the SSGF subsurface are direct evidence that episodic magmatism was localized beneath the Salton Buttes at least since the Mid Pleistocene [28]. Higher solidus temperatures coupled with smaller melt fractions in basaltic crust compared to granitic or metasedimentary compositions and efficient cooling by deep hydrothermal convection may explain the absence of massive crustal melting in a zone of localized spreading and magmatism (Fig. 7).

\section{Conclusions}

(1) Zircon U-Th-O isotopic data for Salton Trough lavas and xenoliths indicate distinct episodes of zircon crystallization between $\sim 30$ and $\sim 9 \mathrm{ka}$ and imply multiple thermal pulses that caused melting and recycling of preexisting basaltic crust;

(2) Zircon $\delta^{18} \mathrm{O}$ compositions (between +1.5 and $+5.0 \%$ ) are lower than typical for continental crust and values achievable by zircons crystallizing from uncontaminated MORB differentiates at $\mathrm{SiO}_{2}>70$ wt.\%. Instead, this requires some form of isotopic exchange with meteoric waters, presumably by deep hydrothermal circulation and alteration;

(3) The Late Quaternary-Holocene zircon ages of rhyolitic lavas and xenoliths and their low $\delta^{18} \mathrm{O}$ imply absence of significant ancient continental basement in the zone of rhyolite generation beneath the Salton Trough. This suggests rupture of preexisting continental crust and formation of new crust composed of dominantly basaltic intrusions and minor differentiated granitic intrusive complexes;

(4) Salton Buttes granophyre xenoliths are among the youngest known granitic rocks on Earth. Their UTh zircon age (ka) indicates rapid (within few $1000 \mathrm{yr}$ ) cooling and crystallization;

(5) Volcanism in the SSGF at the present-day surface is at most Early Holocene in age, consistent with thermal modeling results and radiometric constraints from brines and reservoir rocks that indicate recent heating of the SSGF reservoir rocks.

\section{Acknowledgement}

Comments by P. Robinson on an earlier version of the manuscript and by journal reviewers C. Miller and A. Glazner are acknowledged. R.W. Carlson is thanked for editorial handling. The ion microprobe facility at UCLA is partly supported by a grant from the Instrumentation and Facilities Program, Division of Earth Sciences, National Science Foundation.

\section{Appendix A. Supplementary data}

Supplementary data associated with this article can be found, in the online version, at 10.1016/j.epsl.2006. 09.041 . 


\section{References}

[1] T. Atwater, Implications of plate tectonics for the Cenozoic tectonic evolution of western North America, Geol. Soc. Amer. Bull. 81 (12) (1970) 3513-3535.

[2] W.A. Elders, R.W. Rex, T. Meidav, P.T. Robinson, S. Biehler, Crustal spreading in Southern California, Science 178 (4056) (1972) 15-24.

[3] B.R.T. Simoneit, P.F. Lonsdale, J.M. Edmond, W.C. Shanks III, Deep-water hydrocarbon seeps in Guaymas Basin, Gulf of California, Appl. Geochem. 5 (1-2) (1990) 41-49.

[4] J.M. Stock, K.V. Hodges, Pre-Pliocene extension around the Gulf of California, and the transfer of Baja California to the Pacific Plate, Tectonics 8 (1) (1989) 99-115.

[5] G.J. Axen, J.M. Fletcher, Late Miocene Pleistocene extensional faulting, northern Gulf of California, Mexico and Salton Trough, California, Int. Geol. Rev. 40 (3) (1998) 217-244.

[6] P.F. Lonsdale, Geology and tectonic history of the Gulf of California, in: E.L. Winterer, D.M. Hussong, R.W. Decker (Eds.), The Eastern Pacific Ocean and Hawaii, Geological Society of America, Boulder, 1989, pp. 499-521.

[7] G.S. Fuis, W.D. Mooney, J.H. Healy, G.A. McMechan, W.J. Lutter, A seismic refraction survey of the Imperial Valley region, California, JGR, J. Geophys. Res., B 89 (2) (1984) 1165-1189.

[8] T. Parsons, J. McCarthy, Crustal and upper mantle velocity structure of the Salton Trough, Southeast California, Tectonics 15 (2) (1996) 456-471.

[9] S.P. Larkin, A. Levander, D. Okaya, J.A. Goff, A deterministic and stochastic velocity model for the Salton Trough/Basin and Range transition zone and constraints on magmatism during rifting, J. Geophys. Res., [Solid Earth] 101 (B12) (1996) 27883-27897.

[10] A.H. Lachenbruch, J.H. Sass, S.P. Galanis, Heat-flow in southernmost California and the origin of the Salton Trough, J. Geophys. Res., [Solid Earth Planets] 90 (NB8) (1985) 6709-6736.

[11] P.T. Robinson, W.A. Elders, L.J.P. Muffler, Quaternary volcanism in Salton Sea geothermal field, Imperial-Valley, California, Geol. Soc. Amer. Bull. 87 (3) (1976) 347-360.

[12] C.T. Herzig, D.C. Jacobs, Cenozoic volcanism and two-stage extension in the Salton Trough, Southern California and northern Baja California, Geology 22 (11) (1994) 991-994.

[13] D.J. Cherniak, E.B. Watson, Diffusion in zircon, Rev. Mineral. Geochem. 53 (2003) 113-143.

[14] C.D. Winker, S.M. Kidwell, Paleocurrent evidence for lateral displacement of the Pliocene Colorado River delta by the San Andreas fault system, southeastern California, Geology 14 (9) (1986) 788-791.

[15] S. Larsen, R. Reilinger, Age constraints for the present fault configuration in the Imperial-Valley, California - evidence for Northwestward propagation of the Gulf of California Rift System, J. Geophys. Res., [Solid Earth Planets] 96 (B6) (1991) 10339-10346.

[16] D.P. Zhao, H. Kanamori, E. Humphreys, Simultaneous inversion of local and teleseismic data for the crust and mantle structure of southern California, Phys. Earth Planet. Inter. 93 (3-4) (1996) 191-214.

[17] J.B. Hulen, D. Kaspereit, D.L. Norton, W. Osborn, F.S. Pulka, R.G. Bloomquist, Refined conceptual modeling and a new resource estimate for the Salton Sea geothermal field, Imperial Valley, California, Trans. - Geotherm. Resour. Counc. 26 (2002) 29-36.

[18] P.W. Kasameyer, L.W. Younker, J.M. Hanson, Development and application of a hydrothermal model for the Salton-Sea geothermal-field, California, Geol. Soc. Amer. Bull. 95 (10) (1984) 1242-1252.

[19] M.T. Heizler, T.M. Harrison, The heating duration and provenance age of rocks in the Salton Sea geothermal field, Southern California, J. Volcanol. Geotherm. Res. 46 (1-2) (1991) 73-97.

[20] J.G. Zukin, D.E. Hammond, T.-L. Ku, W.A. Elders, Uraniumthorium series radionuclides in brines and reservoir rocks from two deep geothermal boreholes in the Salton Sea geothermal field, southeastern California, Geochim. Cosmochim. Acta 51 (10) (1987) 2719-2731.

[21] A.E. Williams, M.A. McKibben, A brine interface in the SaltonSea geothermal system, California - fluid geochemical and isotopic characteristics, Geochim. Cosmochim. Acta 53 (8) (1989) 1905-1920.

[22] V.C. Kelley, J.L. Soske, Origin of the Salton volcanic domes, Salton Sea, California, J. Geol. 44 (4) (1936) 496-509.

[23] M.J. Reed, R. Wright, R.G. Richards, Relationship between volcanism and hydrothermal activity at Cerro Prieto, Mexico, Trans. - Geotherm. Resour. Counc. 8 (1984) 217-221.

[24] C.T. Herzig, Geochemistry of igneous rocks from the Cerro Prieto geothermal field, northern Baja California, Mexico, J. Volcanol. Geotherm. Res. 42 (3) (1990) 261-270.

[25] H.P. Taylor Jr., The oxygen isotope geochemistry of igneous rocks, Contrib. Mineral. Petrol. 19 (1) (1968) 1-71.

[26] C. Kendall, Petrology and Stable Isotope Geochemistry of Three Wells in the Buttes Area of the Salton Sea Geothermal Field, Imperial Valley, California, U.S.A., unpublished MSc thesis, University of California Riverside, 1976.

[27] C.T. Herzig, W.A. Elders, Anonymous, Nature and significance of igneous rocks cored in the State 2-14 research borehole; Salton Sea Scientific Drilling Project, California, J. Geophys Res., B, [Solid Earth Planets] 93 (11) (1988) 13,069-13,080.

[28] J. Hulen, F.S. Pulka, Newly-discovered, ancient extrusive rhyolite in the Salton Sea geothermal field, Imperial Valley, California, Proceedings, Twenty-Sixth Workshop on Geothermal Reservoir Engineering SGP-TR-168, Stanford University, Stanford, 2001, pp. 1-16.

[29] R. Hekinian, D. Walker, Diversity and spatial zonation of volcanic rocks from the East Pacific Rise near 21 degrees N, Contrib. Mineral. Petrol. 96 (3) (1987) 265-280.

[30] P.R. Castillo, J.W. Hawkins, P.F. Lonsdale, D.R. Hilton, A.M. Shaw, M.D. Glascock, Petrology of Alarcon Rise lavas, Gulf of California: nascent intracontinental ocean crust, J. Geophys. Res., [Solid Earth] 107 (B10) (2002).

[31] R. Batiza, Geology, petrology, and geochemistry of Isla Tortuga, a recently formed tholeiitic island in the Gulf of California, Geol. Soc. Amer. Bull. 89 (9) (1978) 1309-1324.

[32] J.B. Lowenstern, M.A. Clynne, T.D. Bullen, Comagmatic A-type granophyre and rhyolite from the Alid volcanic center, Eritrea, Northeast Africa, J. Petrol. 38 (12) (1997) 1707-1721.

[33] I. Friedman, J. Obradovich, Obsidian hydration dating of volcanic events, Quat. Res. 16 (1) (1981) 37-47.

[34] P.E. Damon, M. Shafiqullah, K-Ar Dating of Young Volcanic Rocks, University of Arizona, Tuscon, 1991, pp. 1-5.

[35] M.R. Reid, C.D. Coath, T.M. Harrison, K.D. McKeegan, Prolonged residence times for the youngest rhyolites associated with Long Valley Caldera; ${ }^{230} \mathrm{Th}-{ }^{238} \mathrm{U}$ ion microprobe dating of young zircons, Earth Planet. Sci. Lett. 150 (1-2) (1997) 27-39.

[36] J.B. Paces, J.D. Miller Jr., Precise U-Pb ages of Duluth Complex and related mafic intrusions, northeastern Minnesota; geochronological insights to physical, petrogenetic, paleomagnetic, and 
tectonomagnetic processes associated with the $1.1 \mathrm{Ga}$ Midcontinent Rift System, J. Geophys. Res., B, [Solid Earth Planets] 98 (8) (1993) 13,997-14,013.

[37] M. Wiedenbeck, P. Alle, F. Corfu, W.L. Griffin, M. Meier, F. Oberli, Q.A. Von, J.C. Roddick, W. Spiegel, Three natural zircon standards for $\mathrm{U}-\mathrm{Th}-\mathrm{Pb}, \mathrm{Lu}-\mathrm{Hf}$, trace element and REE analyses, Geostand. Newsl. 19 (1) (1995) 1-23.

[38] M. Grove, C.E. Jacobson, A.P. Barth, A. Vucic, Temporal and spatial trends of Late Cretaceous-early Tertiary underplating Pelona and related schist beneath Southern California and southwestern Arizona, Spec. Pap. - Geol. Soc. Am. 374 (2003) 381-406.

[39] S.A. Sanudo-Wilhelmy, A.R. Flegal, Temporal variations in lead concentrations and isotopic composition in the Southern California Bight, Geochim. Cosmochim. Acta 58 (15) (1994) $3315-3320$.

[40] M. Wiedenbeck, J.M. Hanchar, W.H. Peck, P. Sylvester, J. Valley, M. Whitehouse, A. Kronz, Y. Morishita, L. Nasdala, J. Fiebig, I. Franchi, J.P. Girard, R.C. Greenwood, R. Hinton, N. Kita, P.R.D. Mason, M. Norman, M. Ogasawara, P.M. Piccoli, D. Rhede, H. Satoh, B. Schulz-Dobrick, O. Skar, M.J. Spicuzza, K. Terada, A. Tindle, S. Togashi, T. Vennemann, Q. Xie, Y.F. Zheng, Further characterisation of the 91500 zircon crystal, Geostand. Geoanal. Res. 28 (1) (2004) 9-39.

[41] A.L. Booth, Y. Kolodny, P. Chamberlain, M. McWilliams, A.K. Schmitt, J.L. Wooden, Oxygen isotopic composition and $\mathrm{U}-\mathrm{Pb}$ discordance in zircon, Geochim. Cosmochim. Acta 69 (20) (2005) 4895-4905.

[42] N.J.G. Pearce, W.T. Perkins, J.A. Westgate, M.P. Gorton, S.E. Jackson, C.R. Neal, S.P. Chenery, A compilation of new and published major and trace element data for NIST SRM 610 and NIST SRM 612 glass reference materials, Geostand. Newsl. 21 (1995) 115-144.

[43] E.B. Watson, D.A. Wark, J.B. Thomas, Crystallization thermometers for zircon and rutile, Contrib. Mineral. Petrol. 151 (4) (2006) 413-433.

[44] J. Blundy, B. Wood, Mineral-melt partitioning of uranium, thorium and their daughters, Rev. Mineral. Geochem. 52 (2003) $59-123$.

[45] K.L. Brown, C.A. Carter, N.K. Fohey, J.L. Wooden, K. Yi, A.P. Barth, Anonymous, A study of the origin of rhyolite at mid-ocean ridges; geochronology and petrology of trachydacite and rhyolite from Salton Sea, California, and Torfajokull, Iceland, Abstr. Programs - Geol. Soc. Am. 36 (5) (2004) 79.

[46] Y. Chen, P.E. Smith, N.M. Evensen, D. York, K.R. Lajoie, The edge of time; dating young volcanic ash layers with the (super 40) Ar-(super 39) Ar laser probe, Science 274 (5290) (1996) $1176-1178$.

[47] M.S. Sambridge, W. Compston, Mixture modeling of multicomponent data sets with application to ion-probe zircon ages, Earth Planet. Sci. Lett. 128 (3-4) (1994) 373-390.

[48] C.R. Bacon, J.B. Lowenstern, Late Pleistocene granodiorite source for recycled zircon and phenocrysts in rhyodacite lava at Crater Lake, Oregon, Earth Planet. Sci. Lett. 233 (3-4) (2005) 277-293.

[49] O. Sigmarsson, M. Condomines, S. Fourcade, A detailed Th, Sr and $\mathrm{O}$ isotope study of Hekla; differentiation processes in an
Icelandic volcano, Contrib. Mineral. Petrol. 112 (1) (1992) 20-34.

[50] O. Sigmarsson, M. Condomines, S. Fourcade, Mantle and crustal contribution in the genesis of Recent basalts from off-rift zones in Iceland; constraints from Th, Sr and O isotopes, Earth Planet. Sci. Lett. 110 (1-4) (1992) 149-162.

[51] J.W. Valley, J.S. Lackey, A.J. Cavosie, C.C. Clechenko, M.J. Spicuzza, M.A.S. Basei, I.N. Bindeman, V.P. Ferreira, A.N. Sial, E.M. King, W.H. Peck, A.K. Sinha, C.S. Wei, 4.4 billion years of crustal maturation: oxygen isotope ratios of magmatic zircon, Contrib. Mineral. Petrol. 150 (6) (2005) 561-580.

[52] H.P. Taylor Jr., Igneous rocks; II, Isotopic case studies of Circumpacific magmatism, Rev. Miner. 16 (1986) 273-317.

[53] P.W.O. Hoskin, Trace element composition of hydrothermal zircon and the alteration of Hadean zircon from the Jack Hills, Australia, Geochim. Cosmochim. Acta 69 (3) (2005) 637-648.

[54] E.B. Watson, T.M. Harrison, Zircon saturation revisited; temperature and composition effects in a variety of crustal magma types, Earth Planet. Sci. Lett. 64 (2) (1983) 295-304.

[55] J.B. Lowenstern, H.M. Persing, J.L. Wooden, M.A. Lanphere, J.M. Donnelly-Nolan, T.L. Grove, U-Th dating of single zircons from young granitoid xenoliths; new tools for understanding volcanic processes, Earth Planet. Sci. Lett. 183 (1-2) (2000) 291-302.

[56] J.W. Valley, Oxygen isotopes in zircon, Rev. Mineral. Geochem. 53 (2003) 343-385.

[57] S.D. Spulber, M.J. Rutherford, The origin of rhyolite and plagiogranite in oceanic crust; an experimental study, J. Petrol. 24 (1) (1983) 1-25.

[58] T. Chacko, D.R. Cole, J. Horita, Equilibrium oxygen, hydrogen and carbon isotope fractionation factors applicable to geologic systems, Rev. Mineral. Geochem. 43 (2001) 1-81.

[59] J.M. Eiler, Oxygen isotope variations of basaltic lavas and upper mantle rocks, Rev. Mineral. Geochem. 43 (2001) 319-364.

[60] S.M.F. Sheppard, Characterization and isotopic variations in natural waters, Rev. Miner. 16 (1986) 165-183.

[61] K. Muehlenbachs, The Oxygen Isotope Geochemistry of Siliceous Volcanic Rocks From Iceland, 1973.

[62] H. Nicholson, M. Condomines, J.G. Fitton, A.E. Fallick, K. Gronvold, G. Rogers, Geochemical and isotopic evidence for crustal assimilation beneath Krafla, Iceland, J. Petrol. 32 (5) (1991) 1005-1020.

[63] B. Gunnarsson, B.D. Marsh, H.P. Taylor Jr., Generation of Icelandic rhyolites; silicic lavas from the Torfajokull central volcano, J. Volcanol. Geotherm. Res. 83 (1-2) (1998) 1-45.

[64] B.D. Marsh, B. Gunnarsson, R. Congdon, R. Carmody, Hawaiian basalt and Icelandic rhyolite; indicators of differentiation and partial melting, Int. J. Earth Sci. 80 (2) (1991) 481-510.

[65] A.F. Glazner, W. Ussler III, Trapping of magma at midcrustal density discontinuities, Geophys. Res. Lett. 15 (7) (1988) 673-675.

[66] M.S. Ghiorso, R.O. Sack, Chemical mass transfer in magmatic processes. IV. A revised and internally consistent thermodynamic model for the interpolation and extrapolation of liquid-solid equilibria in magmatic systems at elevated temperatures and pressures, Contrib. Mineral. Petrol. 119 (1995) 197-212. 